\title{
ANALISIS PENGEMBANGAN KARIR YANG EFISIEN PADA BADAN KEPEGAWAIAN DAN PENGEMBANGAN SUMBER DAYA MANUSIA (BKPSDM) KOTA SORONG
}

\author{
Rais Dera Pua Rawi', Nur Halina ${ }^{2}$ \\ 1,2 Universitas Muhammadiyah Sorong, Indonesia
}

\begin{abstract}
Abstrak. Sumber daya manusia adalah modal dasar dalam pengembangan karir, oleh karena itu kualitas sumber daya manusia harus dikembangkan dan diarahkan agar bisa mencapai tujuan yang diharapkan. Berbicara mengenai sumber daya manusia sebenarnya dapat dilihat dari 2 aspek kualitas dan aspek kuantitas. perencanaan dan pengembangan karir merupakan strategi sumber daya manusia yang diakui oleh beberapa instansi ataupun perusahaan-perusahaan. Tujuan prinsip programnya adalah untuk membantu para karyawan menganalisis dalam hal kemampuan mereka agar lebih mampu mencocokkan banyak kebutuhan mereka untuk tujuan pertumbuhan dan pengembangan karir dengan kebutuhan perusahaan. Tujuan penelitian ini adalah untuk mengetahuai apakah suatu karir dalam suatu instansi dapat mempengaruhi kinerja pegawai atau tidak. Metode pelaksanaan yang digunakan merupakan metode kualitatif, dan sumber data yang digunakan dalam penulisan menggunakan data primer yang datanya diperoleh secara langsung dari sumber aslinya yang berupa wawancara. sistem pengembangan karir yang bagus, akan memotivasi para karyawan dalam membangun kinerja di organisasi atau perusahaan. Akan tetapi sebaliknya, organisasi atau perusahaan yang tidak memiliki sistem pengembangan karir yang bagus akan mempengaruhi pengembangan karir individu.
\end{abstract}

Kata Kunci : Pengembangan Karir ,Efisien, SDM

\section{PENDAHULUAN}

Mengawali abad ke-20 perusahaan-perusahaan mulai menjadikan Sumber Daya Manusia (SDM) sebagai sumber daya yang penting dari suatu perusahaan sehingga mulai terbentuk adanya departemen sumber daya manusia dalam setiap perusahaan. Sebagai hasilnya banyak perusahaan mulai mengungkapkan tentang perlunya pengembangan karir pada suatu perusahaan. Namun tanggung jawab utama adalah karir terletak pada pribadi sumber daya manusia itu sendiri.

Sumber daya manusia adalah modal dasar dalam pengembangan karir, oleh karena itu kualitas sumber daya manusia harus harus dikembangkan dan diarahkan agar 
bisa mencapai tujuan yang diharapkan. Berbicara mengenai sumber daya manusia sebenarnya dapat dilihat dari 2 aspek kualitas dan aspek kuantitas. Aspek kualitas mencangkup jumlah sumber daya manusia yang tersedia, sedangkan aspek kuantitas mencangkup kemampuan sumber daya manusia baik fisik maupun non fisik atau kecerdasan dan mental dalam pengembangan sumber daya manusia sangat diperlukan, sebab kuantitas sumber daya manusia yang besar tanpa didukung kualitas yang baik akan menjadi beban dalam pengembangan karirnya.

Perencanaan dan pengembangan karir merupakan strategi sumber daya manusia yang diakui oleh beberapa instansi ataupun perusahaan-perusahaan. Tujuan prinsip programnya adalah untuk membantu para karyawan menganalisis dalam hal kemampuan mereka agar lebih mampu mencocokkan banyak kebutuhan mereka untuk tujuan pertumbuhan dan pengembangan karir dengan kebutuhan perusahaan. Selain itu, pengembangan karir merupakan perangkat kritis dimana manajemen bisa meningkatkan produktivitas, meningkatkan sikap karyawan terhadap pekerjaan dan pengembangan kepuasan karyawan yang lebih tinggi.

Rais D.P.Rawi dan M. Arifin Abd.Kadir (2018) menjelaskan bahwa Pengelolaan sumber daya manusia tidak lepas dari faktor pegawai yang diharapkan dapat berprestasi sebaik mungkin demi mencapai tujuan kantor pemerintah. Pegawai merupakan aset utama kantor dan mempunyai peran yang strategis di dalam kantor atau instansi yaitu sebagai pemikir, perencana, dan pengendali aktivitas kantor. Demi tercapainya tujuan kantor, pegawai memerlukan motivasi untuk bekerja lebih rajin. Melihat pentingnya pegawai dalam kantor, maka pegawai diperlukan perhatian lebih serius terhadap tugas yang dikerjakan sehingga tujuan kantor tercapai.

\section{TUJUAN}

Maksud dan tujuan dari proses pelaksanaan kegiatan penelitian ini adalah sebagai berikut :

1. Mahasiswa diharapkan mampu menyesuakian diri dengan dunia kerja yang sesungguhnya, sehingga kulitas, kuantitas dan kinerja yang berasal dari dunia pendidikan dapat dijawab dan dipenuhi.

2. Memperluas pengetahuan mahasiswa dalam memahami situasi, kondisi dalam lingkungan kerja.

3. Untuk mengetahuai apakah suatu karir dalam suatu instansi dapat mempengaruhi kinerja pegawai atau tidak.

4. Meningkatkan produktivitas karyawan maupun instansi 
5. Untuk mengetahui hasil pengembangan karir yang efisiensi di Kantor Badan Kepegawaian dan Pengembangan Sumber Daya Manusia (BKPSDM) Walikota Sorong.

6. Untuk mengetahui tugas utama, fungsi, wewenang, dan tanggung jawab serta satuan kerja di dalam instanasi Kantor Badan Kepegawaian dan Pengembangan Sumber Daya Manusia (BKPSDM) Walikota Sorong.

7. Mengetahui fungsi evaluasi kinerja pegawai di intansi Kantor Badan Kepegawaian dan Pengembangan Sumber Daya Manusia (BKPSDM) Kota Sorong.

8. Agar dapat mengukur kinerja karyawan dan perbaikan pada masa yang akan datang.

9. Agar kariawan lebih baik dalam bekerja dan lebih terinovasi untuk mengembangkan karir kedepan.

\section{METODE}

Metode pelaksanaan yang digunakan merupakan metode penelitian kualitatif, dan sumber data yang digunakan dalam penulisan menggunakan data primer yang datanya diperoleh secara langsung dari sumber aslinya yang berupa wawancara. Dan sebagai pelengkap penelitian dibutuhkan data sekunder sebagi penyempurna dari kurangnya data yang di peroleh baik berupa catatan, bukti yang telah ada, atau arsip baik yang dipublikasikan maupun yang tidak dipublikasikan secara umum.

Tahap Persiapan Kegiatan. Tahap awal persiapan magang oleh mahasiswa adalah menentukan perusahaan atau instansi. Setelah menentukan tempat kegiatan mahasiswa meminta surat pengantar dari kampus untuk diberikan kepada tempat kegiatan. Yang dimana dalam surat pengantar terdapat permohonan untuk melakukan kegiatan pada instansi yang bersangkutan. Sebelum kegiatan dilakukan pihak fakultas ekonomi memberikan pembekalan 2 hari sebelum pelaksanakan kegiatan dilakukan. Sehingga mahasiswa dapat mempersiapkan diri sebelum terjun langsung dalam pelaksanaan kegiatan.

Tahap Pelaksanaan Kegiatan. Setelah surat magang diserahkan dan disetujui pihak instansi Badan Kepegawaian dan Pengembangan Sumber Daya Manusia (BKPSDM) Kota Sorong maka kegiatan dapat dilaksanakan. Kegiatan pertama diawali dengan perkenalan dengan pemimpin dan staf-staf yang terkait didalam instansi. Tahap berikut dalam pelaksanaan kegiatan yaitu, penetapan bidang kerja dan berbagai penjelasan 
terhadap tugas-tugas yang dilakukan dalam instansi Badan Kepegawaian dan Pengembangan Sumber Daya Manusia (BKPSDM). Selama pelaksanaan kegiatan mahasiswa bukan hanya mengerjakan dan belajar memahami proses pengembangan karir yang efisien dalam suatu instansi, tetapi disini mahasiswa mampu memanfaatkan kondisi dalam mengumpulkan data-data yang dibutuhkan dalam pembuatan hasil kegiatan penelitian.

Tahap Akhir Pelaksanaan Kegiatan. Tahap akhir pelaksanaan yang dilakukan oleh mahasiswa adalah menyiapkan suarat pelepasan oleh Fakultas Ekonomi Universitas Muhammadiyah Sorong terhadap instansi Badan Kepegawaian dan Pengembangan Sumber Daya Manusia (BKPSDM) Kota Sorong.

\section{HASIL DAN PEMBAHASAN}

Pengembangan karir pegawai pada kantor Badan Kepegawaian dan Pengembangan Sumber Daya Manusia (BKPSDM) bisa dilakukan melalui dua jalur, yakni melalui pendidikan dan latihan (diklat) dan 9 faktor yang berpengaruh terhadap pengembangan karir pegawai pada Badan Kepegawaian dan Pengembangan Sumber Daya Manusia (BKPSDM) yaitu :

Hubungan pegawai dan instansi. Secara ideal, hubungan pegawai dan instansi berada dalam hubungan yang saling menguntungkan, sehingga pada saat yang demikian organisasi dapat mencapai produktifitas kerja yang lebih tinggi.

Personalia Pegawai. Terkadang, dalam mmanajemen karir pegawai terganggu dengan adanya pegawai yang mempunyai personalitas yang menyimpang, seperti terlau apatis, emosional, ambisius, curang, dan lain-lain. Seorang pegawai yang apatis akan sulit dibina karirnya sebab dirinya sendiri tidak perduli dengan karirnya sendiri.

Faktor Eksternal. Acapkali terjadi semua aturan dalam manajemen karir sebuah instansi menjadi kacau lantaran ada intervensi dari pihak luar.

Politicking dalam instansi. Perencanaan karir akan menjadi sekedar basa- basi ketika ada virus politicking seperti hubungan antar teman, nepotisme, feodalisme, dan lain sebagainya. 
Sistem Penghargaan. Instansi yang tidak mempunyai sistem penghargaan yang jelas (selain gaji dan insentif) akan cenderung memperlakukan pegawainya secara subyektif. Pegawai yang berprestasi baik dianggap sama dengan pegawai yang malas.

Jumlah Pegawai. Semakin banyak jumlah pegawai maka semakin ketat persaingan untuk menduduki jabatan, demikian pula sebaliknya. Jumlah pegawai yang dimilki sebuah instansi sangat mempengaruhi manajemen karir yang ada.

Ukuran Organisasi. Ukuran instansi dalam konteks ini berhubungan dengan jumlah jabatan yang ada dalam intansi tersebut, semakin besar instansi, semakin kompleks urusan manajemen karir pegawai. Namun, kesempatan untuk promosi dan rotasi pegawai juga lebih banyak.

Kultur Instansi. Sebagaimana masyarakat pada umumnya, instansi juga mempunyai kultur. Ada instansi yang berkultur profesional, obyektif, rasional dan demokratik. Namun ada juga instansi yang cenderung feodalistik, rasional dan demokratis. Dan kultur ini sedikit banyak akan mempengaruhi pengembangan karir yang ada dalam instansi tersebut.

Tipe Manajemen. Ada berbagai tipe manajemen di sebuah instansi. Ada manajemen yang lebih cenderung kaku, otoriter, tersentralisir, tertutup, tidak demokratis. Ada juga manajemen yang cenderung fleksibel, paritsipatif, terbuka, dan demokratis. Jika manajemen kaku dan tertutup, maka keterlibatan pegawai dalam pembinaan karirnya sendiri cenderung minimal. Sebaliknya, jika manajemen cenderung terbuka, partisipatif, dan demokratis, maka keterlibatan pegawai dalam pembinaan karir mereka juga cenderung besar.

Cara Membangun Sistem Pengembangan Karir. Dalam mengembangkan sebuah karir, pihak manajemen organisasi atau instansi harus memiliki sebuah sistem pengembangan karir. Ini bertujuan untuk mengelola pengembangan karir karyawan yang obyektif dan efektif. 9 faktor yang mempengaruhi pengembangan karir di atas, merupakan contoh konkrit di mana ada faktor internal dan eksternal yang menghambat pengembangan karir individu. Karena itu, organisasi harus memiliki sistem pengembangan karir yang baik.

Cara membangun sistem pengembangan karir di dalam instansi. Tentukan dulu filosofi perusahaan atau instansi mengenai bagaimana seorang karyawan dapat mengembangkan karirnya di perusahaan, misalnya : 
1). Apakah dasar atau kriteria bagi karyawan untuk naik jabatan (pergerakan vertikal) maupun pindah bagian (pergerakan horisontal) di dalam perusahaan? Kriteria ini bisa beragam, misalnya prestasi kerja karyawan selama beberapa tahun terakhir, seberapa jauh karyawan memenuhi kebutuhan kompetensi dan kualifikasi (sertifikasi, tingkat pendidikan, pengalaman kerja) dari posisi tujuan, tersedianya (kosongnya) posisi tujuan, kesamaan jenis usaha dan lain-lain.

2) Tentukan apakah perpindahan bagian dapat dilakukan pada setiap tingkatan jabatan atau dibatasi, misalnya, hanya pada tingkat karyawan pemula atau junior dan tingkat manajemen saja ? Berapa kali seorang pegawai dapat pindah bagian? Pilihan model yang ada akan memberikan implikasi pada fleksibilitas karyawan dalam membangun karirnya, perencanaan tenagakerja maupun investasi perusahaan di dalam mengembangkan kemampuan karyawannya.

3) Bangun peta pergerakan atau pengembangan karir jabatan-jabatan yang ada (career map) berdasarkan kriteria-kriteria yang telah ditetapkan pada langkah 1 tadi. Untuk memberikan ruang lebih besar bagi karyawan dalam membangun karirnya di dalam organisasi, beberapa organisasi membangun apa yang disebut dengan dual-career atau multiple-career track(s), yaitu jalur karir manajerial (struktural) dan jalur karir non-manajerial (spesialis). Jalur karir non-manajerial/spesialis dibangun untuk memfasilitasi pengembangan karir bagi karyawan yang tidak tertarik menduduki jabatan manajerial - tidak semua orang ingin menjadi manajer, ada yang bahagia menjadi spesialis di dalam disiplin ilmu tertentu. Karena membangun peta karir relatif membutuhkan waktu yang tidak sedikit, fokuskan pembuatan career map pada posisi-posisi yang relatif penting (kritikal) di dalam organisasi.

4) Bangun SOP (standard operating procedure) termasuk alat-alat tes yang diperlukan untuk membantu karyawan mengetahui bagaimana mereka dapat mengembangkan karirnya di dalam organisasi. Langkah-langkah atau proses apa yang harus dilalui ? Misalnya, bagaimana seorang yang baru bekerja dapat menjadi pemimpin divisi atau departemen dalam beberapa tahun ke depan ? Persyaratan maupun tes-tes apakah yang harus dipenuhi dan lain lain. Bagaimana jika seorang pegawai mendapatkan hasil penilaian 
kinerja yang memuaskan selama 3 tahun berturut-turut ? Kemana, kapan, bagaimana dan oleh siapa ia dapat dipromosikan ?

5) Perbaiki terus-menerus model yang telah dibangun berdasarkan hasil implementasinya di lapangan dan kebutuhan organisasi, termasuk bila ada perubahan struktur dan strategi perusahaan. Karena administrasi sistem pengembangan karir itu membutuhkan waktu yang tidak sedikit, persiapkan infrastruktur atau teknologi pendukung agar sistem dapat diimplementasikan dengan efisien dan efektif. Instansi yang memiliki sistem pengembangan karir yang bagus, akan memotivasi para karyawan dalam membangun kinerja di organisasi atau perusahaan. Akan tetapi sebaliknya, organisasi atau perusahaan yang tidak memiliki sistem pengembangan karir yang bagus akan mempengaruhi pengembangan karir individu. Karena peran individu, manajer, dan organisasi sangat berpengaruh dalam pengembangan karir. Ketika individu yang berprestasi tidak didukung sistem organisasi yang baik dan manajer yang tidak mendukung, maka karir individu tersebut tidak akan berubah lebih baik. melalui non diklat. Contoh pengembangan karir melalui diklat misalnya menyekolahkan pegawai (di dalam atau luar negeri), memberi pelatihan (didalam atau diluar organisasi), memberi pelatihan sambil bekerja (on the job training). Sedangkan contoh pengembangan karir melalui non diklat seperti memberi penghargaan kepada pegawai berprestasi \& mempromosikan ke jabatan yang lebih tinggi.

Faktor-faktror yang Mempengaruhi Pengembangan Karir. Terdapat beberapa faktor-faktor yang mempengaruhi pengembangan karir. Secara umum ada 5 faktor yang akan mempengaruhi pengembangan karir seseorang yaitu:

1. Sikap atasan, rekan sekerja dan bawahan

Orang yang beradaptasi dalam bekerja namun tidak disukai oleh orang sekeliling tempat ia bekerja, maka orang yang demikian tidak akan mendapat dukungan untuk meraih karir yang lebih baik. Dengan kata lain, orang yang demikian tidak dipakai dalam organisasi tersebut.

2. Pengalaman

Pengalaman dengan konteks ini berkaitan tingkat golongan (senoritas) seorang pegawai. Dalam mempromosikan para senior bukan hanya mempertimbangkan pengalaman saja tetapi ada pemberian penghargaan terhadap pengabdiannya kepada instansi. 
3. Pendidikan

Faktor pendidikan biasanya menjadi syarat untuk menduduki sebuah jabatan dan mempengaruhi kemulusan karir seseorang akan semakin baik, atau dengan kata lain orang yang berpendidikan lebih tinggi akan memiliki pemikiran yang lebih baik pula.

4. Prestasi

Prestasi dapat saja terjadi dari akumulasi pengalaman, pendidikan dan lingkungan kerja yang baik. Namun prestasi yang baik tentunya merupakan usaha yang kuat dari dalam diri seseorang, walupun karena keterbatasan pendidikan, pengalaman, dukungan rekan-rekan kerja.

5. Faktor Nasib

Faktor nasib juga turut menentukan walaupun porsinya kecih, bahkan para ahli mengatakan faktor nasib berpengaruh terhadap keberhasilan hanya sepuluh persen saja.

Analisis Pelaksanaan Kerja dengan SOP. Setelah menganalisi kinerja pegawai dalam instansi Badan Kepegawaian dan Pengembangan Sumber Daya Manusia (BKPSDM) dengan Standar Operasional Prosedur (SOP) yang ada. Dapat disimpulkan bahwa kegiatan pekerjaan yang dilakukan telah memenuhi Standar Operasional Prosedur (SOP) dari tahap pelayanan, pendataan atau pendaftaran hingga standar waktu yang telah ditetapkan, telah berjalan sesuai prosedur dan tidak menyimpang dari standar operasional prosedur. Dan dengan adanya Standar Operasional Prosedur (SOP) pelayanan PNS atau pegawai dapat menjadi optimal karena pekerjaannya menjadi terstandarkan, efektif dan efisien, akuntabel, konsisten, dan reliable. Dengan menerapkan Standar Operasional Prosedur (SOP) ini maka kesalahan atau kelambatan pelayanan dapat ditelusuri titik permasalahnnya.

\section{KESIMPULAN}

Berdasarkan hasil penelitian pada Instansi Badan Kepegawaian dan Pengembangan Sumber Daya Manusia (BKPSDM) Wali Kota Sorong maka dapat disimpulkan : 
1) Dalam mengembangkan sebuah karir, pihak manajemen organisasi atau instansi harus memiliki sebuah sistem pengembangan karir. Ini bertujuan untuk mengelola pengembangan karir karyawan yang obyektif dan efektif.

2) Bangun SOP (standard operating procedure) termasuk alat-alat tes yang diperlukan untuk membantu karyawan mengetahui bagaimana mereka dapat mengembangkan karirnya di dalam organisasi. Langkahlangkah atau proses apa yang harus dilalui ? Misalnya, bagaimana seorang yang baru bekerja dapat menjadi pemimpin divisi atau departemen dalam beberapa tahun ke depan ? Persyaratan maupun testes apakah yang harus dipenuhi dan lain lain. Bagaimana jika seorang pegawai mendapatkan hasil penilaian kinerja yang memuaskan selama 3 tahun berturut-turut ? Kemana, kapan, bagaimana dan oleh siapa ia dapat dipromosikan?

3) Perbaiki terus-menerus model yang telah dibangun berdasarkan hasil implementasinya di lapangan dan kebutuhan organisasi, termasuk bila ada perubahan struktur dan strategi perusahaan. Karena administrasi sistem pengembangan karir itu membutuhkan waktu yang tidak sedikit, persiapkan infrastruktur atau teknologi pendukung agar sistem dapat diimplementasikan dengan efisien dan efektif. Instansi yang memiliki sistem pengembangan karir yang bagus, akan memotivasi para karyawan dalam membangun kinerja di organisasi atau perusahaan. Akan tetapi sebaliknya, organisasi atau perusahaan yang tidak memiliki sistem pengembangan karir yang bagus akan mempengaruhi pengembangan karir individu.

\section{DAFTAR PUSTAKA}

Asmona, Media, E. 2016. "Evaluasi Kinerja”. http://meidymona.blogspot. in/2016/01/makalah-evaluasi-kinerja.html? $m=1$ Diakses pada Jumat, 15 April 2018 jam 21.08 Wit.

Asmona, Meidya. 2016. "Evaluasi Kinerja". http://meidymona.blogspot. com /2016/01/makalah-evaluasi-kinerja.html. Diakses pada Jumat, 15 April 2018 jam 21.05 Wit. 
Irmawati. 2018. "Interview of Struktur Unit Kerja Badan Kepegawaian dan Pengembangan Sumber Daya Manusia (BKPSDM) Wali Kota Sorong". Jl. Burung Kurana, Remu Utara Kota Sorong.

Ikatan Alumi Universitas Terbuka. 2009. "Makalah Evaluasi Kinerja 1". http://ikautjakarta.blogspot.com/2009/11/makalah-evaluasi-kinerja-1.htm. Diakses pada Jumat, 15 April 2018 jam 21.00 Wit.

Rawi, R. D. P., \& Kadir, M. A. A. (2018). ANALISIS HUBUNGAN MOTIVASI TERHADAP KINERJA PEGAWAI (Studi Kasus Pada Kantor Wali Kota Sorong Papua Barat). MANAJEMEN DEWANTARA, 2(2), 87-94.

Sorong, Kota. "Kota Sorong". https://id.wikipedia.org/wiki/Kota_Sorong. Diakses pada Jumat, 20 April 2018 jam 14.05 Wit.

Sorong, Kota, Wali. 2016. Visi, Misi, dan Struktur Organisasi Badan Kepegawaian dan Pengembangan Sumber Daya Manusia (BKPSDM)”. Jl. Burung Kurana, Remu Utara Kota Sorong.

Wauyi, M. Franklin dan Morin, H. Yorgen. 2017. "Sistem Manajemen Pelayanan Kredit Kepemilikan Usaha pada Bank Papua Cabang Waisai Raja Ampat Papua Barat" Fakultas Ekonomi Universitas Muhammadiyah Sorong. Jl Pendidikan No. 27. Jumat, 15 April 2018 jam 16.00 Wit.

Zunaira, Anis. 2015. "Evaluasi Kinerja". http://aniszunaira.blogspot.in /2015/01 levaluasi-kinerja.html?m=1. Diakses pada Kamis, 19 April 2018 jam 22.00 Wit. 